\title{
Allelopathic potential of the invasive species Aster lanceolatus Willd.
}

\author{
MARIJA NEŠIĆ \\ DRAGICA OBRATOV-PETKOVIĆ \\ DRAGANA SKOČAJIĆ \\ IVANA BJEDOV \\ MATILDA ĐUKIĆ \\ DANIJELA ĐUNISIJEVIĆ-BOJOVIĆ \\ University of Belgrade-Faculty of Forestry \\ Kneza Višeslava 1, 11000 Belgrade, Serbia

\section{Correspondence:} \\ Marija Nešić \\ e-mail:marija.nesic@sfb.bg.ac.rs \\ Keywords: Aster lanceolatus Willd., Compositae,
} invasive plants, allelopathy, bioassay
Received October 10, 2014.

Revised December 04, 2015.

Accepted February 03, 2016.

\begin{abstract}
Background and Purpose: Aster lanceolatus Willd. is a highly invasive plant in Serbia. However, mechanisms that allow A. lanceolatus to be so competitive and to become dominant in riverine plant communities are not clear. Several potentially allelopathic compounds have been identified in A. lanceolatus tissues and those substances could possibly contribute to the rapid spread of this species.
\end{abstract}

Materials and Methods: In this paper, the allelopathic potential of Aster lanceolatus Willd. was studied. Lactuca sativa L. and Sinapis alba L. were selected as the bioassay species. Under laboratory conditions, different concentrations of aqueous extracts of $A$. lanceolatus were applied to determine their effect on seed germination and seedling growth of the test species. Influences of various aqueous extracts on the germination of bioassay species were tested using one-way analysis of variance (ANOVA). In addition, radicle and hypocotyl lengths and dry weight of seedlings were expressed as a percentage of growth inhibition of the control.

Results and Conclusion: The bioassay present in this paper has shown that the aqueous extracts obtained from different vegetative organs of $A$. lanceolatus have an inhibitory effect on seed germination and seedling growth of the test species and that those potentially allelopathic compounds could contribute to the competitive ability of A. lanceolatus against native plants.

\section{INTRODUCTION}

$\mathrm{M}$ any plant communities and their diversity are widely influenced and threatened by invasive plants. Once they are in a new environment, some of the non-native plants have the ability to alter the conditions of ecosystems and thus encourage their competition in relation to other native plants. Some invasive species have biochemicals that may give them an advantage over the native ones, which are facing novel biochemicals (1). Allelochemicals found in different parts of invasive plants (stems, leaves, roots, rhizomes, flowers, pollen and seeds) can have a negative impact on other species. The impacts can be direct, when allelochemicals present in the exudates inhibit germination and seedling development and hinder the formation of stable populations, or indirect, when these substances affect soil organisms (2). Some invasive plants produce allelochemicals that influence various primary and secondary physiological processes in the native species and soil microorganisms, thereby affecting biodiversity (3).

There is a large volume of published studies describing the role of allelochemicals in invasion success. Ridenour and Callaway (4) found 
that Centaurea maculosa Lam. has an allelopathic effect on native Festuca idahoensis Elmer. Allelochemicals extracted via $C$. maculosa root exudates have a large impact on native species while the impact on other non-native species is not as pronounced. However, Callaway et al. (5) found that some individuals of the native species that had survived C. maculosa invasion and were cloned and grown from seeds showed greater resistance to C. maculosa allelochemicals than conspecific individuals that had never experienced invasion. The authors suggested that it is possible that native plants are capable of adapting to the impacts of new allelochemicals. The leaf aqueous extract of some invasive plants reduced the germination and seedling growth of test species in a laboratory bioassay $(8,9,10)$. Several studies have documented that invasive plant allelochemicals can affect mycorrhizae of native plants $(6,7)$ and the activity of pathogenic organisms in the soil (11).

Despite the large number of studies investigating plant allelopathy, little research has been conducted under natural conditions since it is difficult to separate the impact of allelopathic substances from others influences. Laboratory bioassays are widely used to asses potential impacts of allelopathic compounds. Biological tests carried out in laboratory conditions allow researchers to eliminate other alternative interferences through the controlled condition in which the research takes place (12).

Plant habitats and communities along the river are one of the most vulnerable habitats to invasion (13). Aster lanceolatus Willd. is one of the most invasive plants in Serbia along river banks and on the forest edge in wet habitats (14). However, mechanisms that allow A. lanceolatus to be so competitive and to become dominant in riverine plant communities are not clear. Several potentially allelopathic compounds have been identified in A. lanceolatus tissues (15) and it is possible that those substances could contribute to the rapid spread of this species. The objective of this research is to determine the allelopathic potential of aqueous extracts of fresh and dry biomass of Aster lanceolatus Willd. on the germination and seedling growth of bioassay species.

\section{MATERIALS AND METHODS}

\section{Plant material}

To determine the allelopathic potential of $A$. lanceolatus under laboratory conditions, samples of $A$. lanceolatus were collected from Ada Međica, an island on the Sava river in Belgrade. All plants were between 25 and $30 \mathrm{~cm}$ high. Collected plant samples were rinced with tap water and separated into rhizomes, stems and leaves.

Lettuce (Lactuca sativa L.) and mustard (Sinapis alba L.) seeds were used as the bioassay species. L. sativa seeds were purchased from Semenarnacoop (Petrovaradin, Ser- bia) and S. alba seeds were purchased from the Institute of Medicinal Plants Research „Dr Josif Pančić“" (Belgrade, Serbia).

\section{Preparation of aqueous extracts from the fresh tissue of A. lanceolatus}

Aqueous extracts were prepared from fresh rhizomes, stems and leaves. Fifty grams of each type of explants were cut into small pieces and soaked in $250 \mathrm{ml}$ of distilled water for 24 hours at $20^{\circ} \mathrm{C}$ (16). Each aqueous extract was then filtered through four layers of cheesecloth and then through filter paper. The filtrates were diluted to $25 \%$ and $50 \%$ extracts or used as a $100 \%$ extract (16).

\section{Preparation of aqueous extracts from the dry tissue of $\mathbf{A}$. lanceolatus}

Fifty grams of fresh rhizomes, stems and leaves were cut into small pieces and oven-dried at $40^{\circ} \mathrm{C}$ for 48 hours (17). The dried tissue was milled to a powder and added to $250 \mathrm{ml}$ of distilled water to soak for 24 hours. Each aqueous extract was then filtered through filter paper. The filtrates were diluted to $25 \%$ and $50 \%$ extracts or used as a $100 \%$ extract (16).

\section{Bioassays}

In a growth chamber, 15 seeds of Lactuca sativa or Sinapis alba were germinated in $9 \mathrm{~cm}$ Petri dishes on filter paper at $20^{\circ} \mathrm{C}( \pm 2)$ and a $16 \mathrm{~h}$ photoperiod was applied. The effect of $A$. lanceolatus was investigated in the presence of $25 \%, 50 \%$ and $100 \%$ aqueous extracts from its rhizomes, stems and leaves. Treatments were applied in a 5 $\mathrm{ml}$ volume per dish. Distilled water ( $\mathrm{pH}$ 6.81), in the same volume, was used for the control. Treatments were replicated three times. Percentage of seed germination, length of radicles and hypocotyls, and dry seedling weight of bioassay species were recorded after 7 days. Because the rate of seed deterioration after radicle emergence was high, cotyledon expansion was established as a criterion for germination. The number of deteriorated seeds was also recorded. Seedlings were oven-dried at $70^{\circ} \mathrm{C}$ and after 48 hours seedling were weighed.

\section{Data analysis}

Influences of various concentrations of aqueous extracts on the germination of bioassay species were tested using one-way analysis of variance (ANOVA) followed by Fisher's LSD test $(\mathrm{P}<0.05)$. Radicle and hypocotyl lengths and dry weight of seedlings were expressed as $\%$ of growth inhibition of the control, based on the formula (17):

$$
\% \text { growth inhibition }=100(\mathrm{pc}-\mathrm{pt}) / \mathrm{pc}
$$

where pc and pt are the radicle or hypocotyl length or dry weight of seedlings of the control and the treated sample, respectively. 


\section{RESULTS}

\section{Effects of A. lanceolatus extracts on the seed germination of bioassay species}

The aqueous extract of fresh plant tissue had an effect on the germination of both test species (Table 1). This was especially pronounced in the germination of $S$. alba. The extract of the stem significantly reduced the germination of $S$. alba in all concentrations. In addition, the germination of $S$. alba was reduced significantly by $50 \%$ and $25 \%$ rhizome extracts and $100 \%$ and $25 \%$ leaf extracts, while in the presence of a $100 \%$ rhizome extract and a $50 \%$ leaf extract germination was reduced but not significantly. Extracts made of fresh vegetative parts had similar effects on the seed germination of $L$. sativa, but those effects where not so pronounced compared to $S$. alba. However, the $50 \%$ stem extract and the $50 \%$ rhizome extract significantly reduced the germination of target species.

Extracts made from dry vegetative parts of $A$. lanceolatus significantly reduced germination in all concentrations, except in treatments with the lowest concentration of extracts where the germination of the test species was without a significant decrease (Table 1). A decrease in the germination percentage was particularly pronounced in treatments with the stem extract in the highest concentration, and in treatments with the rhizome extract in the highest and the $50 \%$ concentration. The germination of L. sativa was also affected by extracts of all vegetative parts in all concentrations, but the most prominent effects were produced by extracts of the rhizome $(100 \%, 50 \%)$, following the extracts of the stem $(50 \%, 25 \%)$ and leaf (25\%).
During the experiment, seed deterioration of bioassay species was observed (Table 2).

After the third day of the germination experiment, many seeds with a sprouted radicle stopped developing. This was especially noticeable for $S$. alba in all three treatments with extracts made from fresh vegetative parts. Sinapis seeds also deteriorated after the treatment with the extract of dry vegetative parts of $A$. lanceolatus, especially in treatments with the stem extract in all concentrations. L. sativa seeds deteriorated in treatments with $50 \%$ stem and rhizome extracts and a $100 \%$ leaf extract made from fresh tissue and 50\% rhizome and 50\% and 25\% leaf extracts from dry tissue. There was no seed deterioration in control treatments.

\section{Effects of A. lanceolatus extracts on the seedling growth of bioassay species}

A. lanceolatus extracts affected the dry weight of seedlings of both bioassay species (Table 3). All treatments led to the reduction in biomass of $S$. alba seedlings compared to the control, except for treatments with dry leaf and stem extracts in the lowest concentrations. The reduction in $S$. alba seedlings biomass was highest in the presence of $100 \%$ stem and rhizome extracts and a $50 \%$ dried rhizome extract. Extracts obtained from fresh and dry vegetative parts reduced the biomass of $L$. sativa seedlings by more than $75 \%$ compared to control treatments, except for the lowest concentration of the fresh stem extract, which reduced biomass by $15.08 \%$.

A. lanceolatus fresh and dry tissue extracts inhibited the growth of the radicle of $S$. alba in all concentrations (Table 4).

Table 1. Effects of A. lanceolatus extracts on the seed germination of bioassay species

\begin{tabular}{|c|c|c|c|c|c|}
\hline \multirow{3}{*}{$\begin{array}{l}\text { Vegetative part } \\
\text { used for extract } \\
\text { preparation }\end{array}$} & \multirow{3}{*}{$\begin{array}{l}\text { Extract } \\
\text { conc. } \\
\%)\end{array}$} & \multicolumn{4}{|c|}{ Germination percentage (\%) } \\
\hline & & \multicolumn{2}{|c|}{ Aqueous extracts from fresh vegetative parts } & \multicolumn{2}{|c|}{ Aqueous extracts from dry vegetative parts } \\
\hline & & S. alba & L. sativa & S. alba & L. sativa \\
\hline \multirow{2}{*}{ control } & 0 & $84.47^{\mathrm{a}} \pm 2.233$ & $80^{\mathrm{a}} \pm 7.679$ & $84.47^{\mathrm{a}} \pm 2.233$ & $80^{\mathrm{a}} \pm 7.679$ \\
\hline & 100 & $42.23^{\mathrm{d}} \pm 12.38$ & $80^{\mathrm{a}} \pm 3.868$ & $20^{\mathrm{d}} \pm 3.868$ & $68.9^{\mathrm{ab}} \pm 5.877$ \\
\hline \multirow{3}{*}{ stem } & 50 & $55.57^{\mathrm{cd}} \pm 12.37$ & $48.9^{\mathrm{b}} \pm 8.02$ & $66.67^{\mathrm{bc}} \pm 3.839$ & $57.8^{\mathrm{bcd}} \pm 5.877$ \\
\hline & 25 & $60^{\text {bcd }} \pm 7.679$ & $66.7^{\mathrm{ab}} \pm 11.547$ & $82.2^{\mathrm{a}} \pm 5.877$ & $55.5^{\text {bcd }} \pm 2.233$ \\
\hline & 100 & $77.8^{\mathrm{ab}} \pm 5.877$ & $71.1^{\mathrm{ab}} \pm 11.1$ & $13.37^{\mathrm{d}} \pm 6.667$ & $51.1^{\mathrm{bcd}} \pm 5.877$ \\
\hline \multirow{3}{*}{ rhizome } & 50 & $60^{\text {bcd }} \pm 3.868$ & $55.6^{\mathrm{b}} \pm 5.884$ & $13.33^{\mathrm{d}} \pm 3.839$ & $42.2^{\mathrm{d}} \pm 7.997$ \\
\hline & 25 & $62.23^{\mathrm{bcd}} \pm 7.997$ & $55.5^{\mathrm{b}} \pm 9.678$ & $73.3^{\mathrm{abc}} \pm 0$ & $62.2^{\mathrm{abc}} \pm 5.877$ \\
\hline & 100 & $51.1^{\mathrm{d}} \pm 2.2$ & $66.7^{\mathrm{ab}} \pm 3.839$ & $62.23^{c} \pm 9.678$ & $64.5^{\mathrm{ab}} \pm 2.233$ \\
\hline \multirow{2}{*}{ leaf } & 50 & $73.33^{\mathrm{abc}} \pm 7.708$ & $57.8^{\mathrm{ab}} \pm 5.877$ & $66.63^{\mathrm{bc}} \pm 6.667$ & $64.4^{\mathrm{ab}} \pm 5.884$ \\
\hline & 25 & $53.3^{\mathrm{cd}} \pm 0$ & $57.8^{\mathrm{ab}} \pm 5.877$ & $80^{\mathrm{ab}} \pm 0$ & $44.4^{\mathrm{cd}} \pm 8.02$ \\
\hline
\end{tabular}

Values with a common letter within column are not significantly different at $<0.05$. Values are means $\pm s$.e. of three replicates. 
Table 2. Seed deterioriation of the bioassay species. Percentages of vital seeds in treatments on the first (I), third (III) and seventh (VII) day of the experiment are shown.

\begin{tabular}{|c|c|c|c|c|c|c|c|c|c|c|c|c|c|}
\hline \multirow{3}{*}{$\begin{array}{l}\text { Vegetative part } \\
\text { used for extract } \\
\text { preparation }\end{array}$} & \multirow{3}{*}{$\begin{array}{l}\text { Extract } \\
\text { conc. } \\
(\%)\end{array}$} & \multicolumn{6}{|c|}{ Aqueous extracts from fresh vegetative parts } & \multicolumn{6}{|c|}{ Aqueous extracts from dry vegetative parts } \\
\hline & & \multicolumn{3}{|c|}{ S. alba } & \multicolumn{3}{|c|}{ L. sativa } & \multicolumn{3}{|c|}{ S. alba } & \multicolumn{3}{|c|}{ L. sativa } \\
\hline & & I & III & VII & I & III & VII & I & III & VII & I & III & VII \\
\hline control & 0 & 44.44 & 80.00 & 84.47 & 2.22 & 62.22 & 80.00 & 44.44 & 80.00 & 84.47 & 2.22 & 62.22 & 80.00 \\
\hline \multirow{3}{*}{ stem } & 100 & 2.22 & 66.67 & 42.22 & 0.00 & 75.56 & 80.00 & 2.22 & 55.56 & 20.0 & 0.00 & 46.67 & 55.5 \\
\hline & 50 & 11.11 & 80.00 & 55.55 & 4.44 & 51.11 & 48.89 & 24.44 & 53.33 & 13.4 & 4.44 & 48.89 & 51.1 \\
\hline & 25 & 35.56 & 82.22 & 60.00 & 2.22 & 62.22 & 66.67 & 60.00 & 84.44 & 62.2 & 13.33 & 53.33 & 64.5 \\
\hline \multirow{3}{*}{ rhizome } & 100 & 26.67 & 80.00 & 77.80 & 2.22 & 68.89 & 71.13 & 11.11 & 53.33 & 66.7 & 4.44 & 53.33 & 68.9 \\
\hline & 50 & 24.44 & 62.22 & 60.00 & 13.33 & 64.44 & 55.55 & 40.00 & 57.78 & 13.3 & 2.22 & 51.11 & 42.2 \\
\hline & 25 & 15.56 & 82.22 & 62.22 & 2.22 & 53.33 & 55.55 & 57.78 & 82.22 & 66.6 & 4.44 & 64.44 & 64.4 \\
\hline \multirow{3}{*}{ leaf } & 100 & 0.00 & 66.67 & 51.11 & 0.00 & 71.11 & 66.67 & 0.00 & 53.33 & 82.2 & 0.00 & 51.11 & 57.8 \\
\hline & 50 & 6.67 & 86.67 & 73.33 & 6.67 & 53.33 & 57.78 & 17.78 & 68.89 & 73.3 & 0.00 & 68.89 & 62.2 \\
\hline & 25 & 6.67 & 68.89 & 53.33 & 0.00 & 57.78 & 57.78 & 35.56 & 86.67 & 80.0 & 4.44 & 53.33 & 44.4 \\
\hline
\end{tabular}

Table 3. Dry seedlings biomass reduction in the treatments compared to the control (\%).

\begin{tabular}{|c|c|c|c|c|c|}
\hline \multirow{2}{*}{$\begin{array}{l}\text { Vegetative part } \\
\text { used for extract } \\
\text { preparation }\end{array}$} & \multirow{2}{*}{$\begin{array}{l}\text { Extract } \\
\text { conc. } \\
(\%)\end{array}$} & \multicolumn{2}{|c|}{ Aqueous extracts from fresh vegetative parts } & \multicolumn{2}{|c|}{ Aqueous extracts from dry vegetative parts } \\
\hline & & S. alba & L. sativa & S. alba & L. sativa \\
\hline \multirow{2}{*}{ control } & 0 & 0.00 & 0.00 & 0.00 & 0.00 \\
\hline & 100 & 53.15 & 76.66 & 86.53 & 79.51 \\
\hline \multirow{3}{*}{ stem } & 50 & 26.94 & 85.94 & 18.46 & 76.20 \\
\hline & 25 & 20.44 & 15.08 & -1.82 & 77.48 \\
\hline & 100 & 15.06 & 77.48 & 90.31 & 85.48 \\
\hline \multirow{3}{*}{ rhizome } & 50 & 35.43 & 80.52 & 86.07 & 86.49 \\
\hline & 25 & 30.21 & 85.85 & 7.18 & 79.41 \\
\hline & 100 & 43.67 & 78.49 & 25.89 & 75.65 \\
\hline \multirow{2}{*}{ leaf } & 50 & 6.13 & 82.91 & 24.30 & 75.37 \\
\hline & 25 & 37.84 & 81.99 & -7.02 & 78.31 \\
\hline
\end{tabular}

Table 4. Inhibition of radicle growth of seedlings in the treatments compared to the control (\%)

\begin{tabular}{|c|c|c|c|c|c|}
\hline \multirow{2}{*}{$\begin{array}{l}\text { Vegetative part } \\
\text { used for extract } \\
\text { preparation }\end{array}$} & \multirow{2}{*}{$\begin{array}{l}\text { Extract } \\
\text { conc. } \\
(\%)\end{array}$} & \multicolumn{2}{|c|}{ Aqueous extracts from fresh vegetative parts } & \multicolumn{2}{|c|}{ Aqueous extracts from dry vegetative parts } \\
\hline & & S. alba & L. sativa & S. alba & L. sativa \\
\hline \multirow{2}{*}{ control } & 0 & 0.00 & 0.00 & 0.00 & 0.00 \\
\hline & 100 & 91.32 & 28.35 & 97.16 & 73.00 \\
\hline \multirow{3}{*}{ stem } & 50 & 72.19 & -11.88 & 87.04 & 29.49 \\
\hline & 25 & 71.77 & 6.76 & 15.63 & 14.72 \\
\hline & 100 & 45.77 & -10.13 & 97.62 & 89.57 \\
\hline \multirow{3}{*}{ rhizome } & 50 & 66.60 & 0.42 & 98.50 & 77.67 \\
\hline & 25 & 57.39 & 17.79 & 96.59 & 82.45 \\
\hline & 100 & 90.77 & 28.29 & 77.53 & 53.34 \\
\hline \multirow{2}{*}{ leaf } & 50 & 63.79 & 26.18 & 64.15 & 40.05 \\
\hline & 25 & 42.58 & 15.44 & 37.87 & 36.25 \\
\hline
\end{tabular}


The percentage of inhibition ranged from $15.63 \%$ to $98.50 \%$. The reduction was especially pronounced in the fresh stem extract in all concentrations and in the 100\% and $50 \%$ dry stem extracts. In addition, a decrease in radicle growth was noticed in treatments with dry rhizome extracts in all concentrations, and with fresh and dry leaf extracts in the highest concentration (Table 4). Likewise, hypocotyl length was reduced as a result of the treatments (Table 5). The highest reduction was in the treatment with the dry stem extract $(83.79 \%)$ and in treatments with $100 \%$ and $50 \%$ dry rhizome extracts (86.77\% and $87.12 \%$, respectively).

Extracts of fresh vegetative parts had a lower impact on hypocotyl growth of $S$. alba. The lowest concentration of these extracts encouraged hypocotyl elongation, compared to control treatments. Extracts of fresh steam, in $50 \%$ concentration and $100 \%$ rhizome extract promoted L. sativa radicle elongation while other extracts of fresh vegetative parts inhibited radicle growth compared to control treatments. Extracts of dry vegetative parts showed inhibitory effects on radicle growth of test species and the percentage of inhibition ranged from $14.72 \%$ to $89.57 \%$. Hypocotyl length of test species L. sativa was higher in the treatment with extract of fresh vegetative parts than in control treatments. In addition, 50\% and $25 \%$ extracts of dried stem and leaf had a similar effect on the length of the hypocotyl, while the $25 \%$ extract of dry rhizomes had the highest inhibitory effect on hypocotyl length of L. sativa.

\section{DIsCusSION}

Bioassay presented in this paper has shown that the extracts obtained from different vegetative parts of $A$. lanceolatus, negatively affect seed germination and seedling growth of test species in laboratory conditions. The present findings are consistent with research of Dias et al. (18) which found that aromatic water of $A$. lanceolatus inhibited germination and hypocotyl growth of Lactuca sativa. Inhibited or delayed germination and lower seedling development are secondary indicators of primary influence of allelochemicals on metabolic processes (19). Both types of test species have shown sensitivity to extracts. In addition, reduction in seed germination was significant and inhibition of the seedling growth was by more than $75 \%$ compared to control treatments, in some cases. However, it should be noted that the biological tests carried out under controlled conditions, such as Petri dishes, probably overestimate the effect of allelopathy since soil can significantly neutralize effects of secondary metabolites $(20,21)$.

Although Rice (22) defined allelopathy as positive or negative impacts of a plant on another plant and some extracts of $A$. lanceolatus stimulated elongation of the hypocotyl and the radicle of the test species, this cannot be rated as a positive effect, since seedling biomass was lower compared to the control. The phytotoxic effect of the applied extracts was corroborated by the decay of seeds caused after the radicle ruptured the seed coat.

Plant secondary metabolites can alter ecosystem components, which can influence the processes and relationships in an ecosystem and, consequently, induce changes within plant communities $(21,23)$. Sharma and Raghubanshi (24) suggested that allelopathic activity of invasive Lantana camara L. affects the structure of the forest by changing the soil $\mathrm{pH}$. Low floristic diversity in a community with one or two dominant species allows one species to "take over" in controlling the biochemical processes of the soil, which can greatly affect other plants in the community (21). Therefore, the influence of allelopathic compounds can be more pronounced in communities that are characterized by a low floristic diversity, compared to communities comprised of a large number of species (21). A. lanceolatus occupies new habitats via sexual reproduction followed by seed dispersal, and continues to spread

Table 5. Inhibition of the hypocotyl growth of the seedlings in the treatment compared to the control (\%)

\begin{tabular}{|c|c|c|c|c|c|}
\hline \multirow{2}{*}{$\begin{array}{l}\text { Vegetative part } \\
\text { used for extract } \\
\text { preparation }\end{array}$} & \multirow{2}{*}{$\begin{array}{l}\text { Extract } \\
\text { conc. } \\
(\%)\end{array}$} & \multicolumn{2}{|c|}{ Aqueous extracts from fresh vegetative parts } & \multicolumn{2}{|c|}{ Aqueous extracts from dry vegetative parts } \\
\hline & & S. alba & L. sativa & S. alba & L. sativa \\
\hline \multirow{2}{*}{ control } & 0 & 0.00 & 0.00 & 0.00 & 0.00 \\
\hline & 100 & 39.97 & -37.06 & 83.79 & 16.40 \\
\hline \multirow{3}{*}{ stem } & 50 & 2.62 & -56.16 & 33.46 & -31.14 \\
\hline & 25 & -7.13 & -34.92 & 6.98 & -44.93 \\
\hline & 100 & 9.27 & -65.05 & 86.77 & 61.00 \\
\hline \multirow{3}{*}{ rhizome } & 50 & 8.54 & -150.70 & 87.12 & 2.78 \\
\hline & 25 & -6.48 & -56.24 & 45.87 & 16.40 \\
\hline & 100 & 55.56 & -65.42 & 44.62 & 7.14 \\
\hline \multirow[t]{2}{*}{ leaf } & 50 & 13.83 & -117.49 & 10.11 & -16.29 \\
\hline & 25 & -18.63 & -64.11 & 20.93 & -19.27 \\
\hline
\end{tabular}


via rhizomes forming monodominant stands. Taking into account that $A$. lanceolatus is perennial and perennials release exudates into the soil over several growing seasons, the results of this study could explain the high number of individuals of this invasive species.

Non-native species can affect the biodiversity of an ecosystem by altering the dynamics of succession (25). By changing environmental conditions in an ecosystem, some non-native plants ensure their survival and hinder or prevent the development of plants that occur in the later stages of succession (26). In addition, some allelochemicals lead to poor accessibility of nutrients by inhibiting the development of nitrifying plants and organisms and thus alter the floristic composition and succession of communities (27). Obratov-Petković et al. (28) reported that A. lanceolatus is the edificator in the Asteretum lanceolati community. The community consists of 107 species (28), of which $16 \%$ are invasive. It is known that coexisting species are adapted to each other's metabolites produced during evolution $(29,30)$. When a non-native species with allelopathic ability enters a new community, it can become more competitive compared to native plants, which are vulnerable to new allelochemicals. It is possible that phytotoxic compounds of $A$. lanceolatus inhibit the development of indigenous flora, which creates empty space on the site and causes increased nutrient availability. Increase in the amount of accessible resources in an ecosystem increases the susceptibility of ecosystems to invasion (31). Thus, the allelopathic ability of edificator species could explain the existence of a large number of invasive species in the Asteretum lanceolati community.

The biological test described in this paper showed that extracts have an impact on tested species and provides justification for further analysis in order to determine active substances and their role in other physiological processes. However, various components of an ecosystem are closely interlinked and factors that change one component often have an indirect impact on other components. Therefore, the results of this study should be confirmed and supplemented by additional experiments in natural conditions in order to determine the exact role of allelochemicals in the spread of this invasive species. This is especially important because different plant species can exhibit different reactions to same treatments. In addition, potential effect on co-occurring natives should preferably be tested, in order to make any conclusions on the role of allelopathy in a specific community.

Acknowledgements: This paper was realized as a part of the project "Studying climate change and its influence on the environment: impacts, adaptation and mitigation" (43007) financed by the Ministry of Education and Science of the Republic of Serbia within the framework of integrated and interdisciplinary research for the period 2011-2014.

\section{REFERENCES}

1. CALLAWAY R M, RIDENOUR W M 2004 Novel Weapons: Invasive Success and the Evolution of Increased Competitive Ability. Frontiers in Ecology and the Environment 2(8): 436-43 http://dx.doi.org/10.1890/1540-9295(2004)002[0436:NWISAT] 2.0.CO;2

2. LEVINE J M, ADLER P B, YELENIK S G 2004 A meta-analysis of biotic resistance to exotic plant invasions. Ecology Letters 7(10): 975-89 http://dx.doi.org/10.1111/j.1461-0248.2004.00657.x

3. LORENZO P, HUSSAIN M I, GONZÁLEZ L. 2013 Role of allelopathy during invasion process by alien invasive plants in terrestrial ecosystems. In: Cheema A., Farooq M., Wahid A. (eds.) Allelopathy: Current Trends and Future Applications, Springer, Berlin, Germany, p 517 http://dx.doi.org/10.1007/978-3-642-30595-5_1

4. RIDENOUR W M, CALLAWAY R M 2001 The Relative Importance of Allelopathy in Interference: The Effects of an Invasive Weed on a Native Bunchgrass. Oecologia 126(3): 444-50 http://dx.doi.org/10.1007/s004420000533

5. CALLAWAY R M, RIDENOUR W M, LABOSKI T, WEIR T, VIVANCO J M 2005 Natural selection for resistance to the allelopathic effects of invasive plants. Journal of Ecology 93(3): 576-83 http://dx.doi.org/10.1111/j.1365-2745.2005.00994.x

6. MALLIK A U, QUAYYUM H A 1997 Allelopathic potential of large-leaved aster (Aster macrophyllus L.): A Preliminary Study. Ont. Min. Natur. Resour. Northwest Sci. \& Technol. Thunder Bay, Ont. TR-108, p 8

7. CSISZAR A, KORDA M, SCHMIDT D, ŠPORČIĆ D, SUELE P, TELEKI B, TIBORCZ V, ZAGYVAI G, BARTHA D 2013 Allelopathic potential of some invasive plant species occurring in Hungary. Allelopathy J 31(2): 309-18

8. ZHIZHONG Z, QIUXIANG S, ZHIHAO S, MAOFENG L 2013 Allelopathy of the invasive plant Alternanthera philoxeroides to radish and lettuce. Acta Prataculturae Sinica 22(1): 288-93

9. CALLAWAY R M, CIPOLLINI D, BARTO K, THELEN G C, HALLETT S G, PRATI D, STINSON K, KLIRONOMOS J 2008 Novel Weapons: Invasive Plant Suppresses Fungal Mutualists in America but Not in Its Native Europe. Ecology 89(4): 1043-55 http://dx.doi.org/10.1890/07-0370.1

10. PRATI D, BOSSDORF O 2004 Allelopathic inhibition of germination by Alliaria petiolata (Brassicaceae). American Journal of Botany 91(2): 285-8 http://dx.doi.org/10.3732/ajb.91.2.285

11. ZHANG S, JIN Y, TANG J, CHEN X 2009 The invasive plant Solidago canadensis L. suppresses local soil pathogens through allelopathy. Applied soil ecology 41(2): 215-22

http://dx.doi.org/10.1016/j.apsoil.2008.11.002

12. DAKSHINI K 1995 On laboratory bioassays in allelopathy. The Botanical Review 61(1): 28-44 http://dx.doi.org/10.1007/BF02897150

13. DYAKOV N, ZHELEV P 2013 Alien species invasion and diversity of riparian forest according to environmental gradients and disturbance regime. Applied Ecology and Environmental Research 11(2): 249-72 http://dx.doi.org/10.15666/aeer/1102_249272

14. OBRATOV-PETKOVIĆ D, BJEDOV I, RADULOVIĆ S, SKOČAJIĆ D, ĐUNISIJEVIĆ-BOJOVIĆ D, ĐUKIĆ M 2009 Ecology and distribution of an invasive species Aster lanceolatus Willd. on wet habitats in Belgrade. Bulletin of the Faculty of Forestry 100: 159-78 http://dx.doi.org/10.2298/GSF0900159O

15. CHMIELEWSKI J G, SEMPLE J C 2001 The biology of Canadian weeds. 113. Symphyotrichum lanceolatum (Willd.) Nesom [Aster lanceolatus Willd.] and S. lateriflorum (L.) Löve \& Löve [Aster lateriflorus (L.) Britt.]. Canadian Journal of Plant Science 81(4): 829-49 http://dx.doi.org/10.4141/P00-056 
16. KIL B-S, YUN K 1992 Allelopathic effects of water extracts of Artemisia princeps var. orientalis on selected plant species. Journal of Chemical Ecology 18(1): 39-51 http://dx.doi.org/10.1007/BF00997163

17. OTHMAN M R, LEONG S T, BAKAR B, AWANG K, ANNUAR M S M 2012 Allelopathic Potentials of Cuscuta campestris Yuncker Extracts on Germination and Growth of Radish (Raphanus sativus L.) and Lettuce (Lactuca sativa L.). Journal of Agricultural Science 4(9): 57-63 http://dx.doi.org/10.5539/jas.v4n9p57

18. DIAS J D F G, MIGUEL O G, MIGUEL M D 2009 Composition of essential oil and allelopathic activity of aromatic water of Aster lanceolatus Willd. (Asteraceae). Brazilian Journal of Pharmaceutical Sciences 45(3): 469-74

19. KRUSE M, STRANDBERG M, STRANDBERG B 2000 Ecological Effects of Allelopathic Plants - a Review. National Environmental Research Institute, Silkeborg, Denmark, p 66

20. KROGMEIER M, BREMNER J 1989 Effects of phenolic acids on seed germination and seedling growth in soil. Biology and fertility of soils 8(2): 116-22 http://dx.doi.org/10.1007/BF00257754

21. WARDLE D A, NILSSON M C, GALLET C, ZACKRISSON O 1998 An ecosystem-level perspective of allelopathy. Biological Reviews 73(3): 305-19 http://dx.doi.org/10.1017/S0006323198005192

22. RICE E L. 1984 Allelopathy. Academic press, Orlando, p 422

23. WARDLE D A, KARBAN R, CALLAWAY R M 2011 The ecosystem and evolutionary contexts of allelopathy. Trends in ecology \& evolution 26(12): 655-62 http://dx.doi.org/10.1016/j.tree.2011.08.003

24. SHARMA G P, RAGHUBANSHI A 2007 Effect of Lantana camara L. cover on local depletion of tree population in the Vind- hyan tropical dry deciduous forest of India. Applied Ecology and Environmental Research 5(1): 109-21 http://dx.doi.org/10.15666/aeer/0501_109121

25. HOBBS R J, HIGGS E S, HALL C. 2013 Novel ecosystems: intervening in the new ecological world order. Wiley-Blackwell, Oxford, UK, p 380 http://dx.doi.org/10.1002/9781118354186

26. DAVIS M A. 2009 Invasion biology. Oxford, Oxford University Press, Oxford, UK, p 264

27. BAZZAZ F 1979 The physiological ecology of plant succession. Annual review of ecology and systematics 10: 351-71 http://dx.doi.org/10.1146/annurev.es.10.110179.002031

28. OBRATOV-PETKOVIĆ D, BJEDOV I, SKOČAJIĆ D, ĐUNISIJEVIĆ-BOJOVIĆ D, ĐUKIĆ M, GRBIĆ M $2011 A_{s-}$ teretum lanceolati: Xenospontaneous community on wet and riparian habitats. Bulletin of the Faculty of Forestry 103: 73-92 http://dx.doi.org/10.2298/GSF1103073O

29. THORPE A S, THELEN G C, DIACONU A, CALLAWAY R M 2009 Root exudate is allelopathic in invaded community but not in native community: field evidence for the novel weapons hypothesis. Journal of Ecology 97: 641-45 http://dx.doi.org/10.1111/j.1365-2745.2009.01520.x

30. WARDLE D A, KARBAN R, CALLAWAY R M 2011 The ecosystem and evolutionary contexts of allelopathy. Trends in Ecology \& Evolution 26: 655-62 http://dx.doi.org/10.1016/j.tree.2011.08.003

31. DAVIS M A, GRIME J P, THOMPSON K 2000 Fluctuating resources in plant communities: a general theory of invasibility. Journal of Ecology 88(3): 528-34 http://dx.doi.org/10.1046/j.1365-2745.2000.00473.x 